\title{
Glibenclamide activates translation in rat pancreatic beta cells through calcium-dependent mTOR, PKA and MEK signalling pathways
}

\author{
Q. Wang $\cdot$ H. Heimberg $\cdot$ D. Pipeleers $\cdot$ Z. Ling
}

Received: 11 January 2008 / Accepted: 4 April 2008 / Published online: 21 May 2008

(C) Springer-Verlag 2008

\begin{abstract}
Aims/hypothesis Prolonged exposure of rat beta cells to the insulin secretagogue glibenclamide has been found to induce a sustained increase in basal insulin synthesis. This effect was calcium-dependent and localised in cells that had been degranulated by the drug. Since it was blocked by the translation inhibitor cycloheximide, we examined whether sustained exposure to glibenclamide activates translational factors by calcium-dependent signalling pathways.

Methods Purified rat beta cells were cultured with and without glibenclamide in the presence or absence of inhibitors of calcium-dependent signalling pathways before measurement of basal and stimulated protein and insulin synthesis, and assessment of abundance of (phosphorylated) translation factors.

Results A $24 \mathrm{~h}$ exposure to glibenclamide induced activation of four translation factors, i.e. phosphorylation of eukaryotic initiation factor (eIF) $4 \mathrm{e}$ binding protein 1 and ribosomal protein S6 (rpS6), and dephosphorylation of eIF- $2 \alpha$ and eukaryotic elongation factor 2 . The rise in phospho-rpS6 intensity was localised to a subpopulation of beta cells with low insulin content. This activation of translational factors and the associated elevation of insulin synthesis were completely blocked
\end{abstract}

Q. Wang $\cdot$ H. Heimberg $\cdot$ D. Pipeleers $\cdot$ Z. Ling $(\triangle)$

Diabetes Research Center, Brussels Free University-VUB

and JDRF Center for Beta Cell Therapy in Diabetes,

Laarbeeklaan 103,

1090 Brussels, Belgium

e-mail: zhidong.ling@vub.ac.be

\section{Z. Ling}

Endocrine and Metabolic Division,

E-Institutes of Shanghai Universities,

Shanghai Clinical Center for Endocrine \& Metabolic Diseases,

Shanghai, China by the calcium channel blocker verapamil and partially blocked by the mammalian target of rapamycin (mTOR) inhibitor rapamycin, the protein kinase A (PKA) inhibitor Rp8-Br-cAMPs and the mitogen-activated protein kinase/ extracellular signal-regulated kinase kinase (MEK) inhibitor U0126; a combination of inhibitors exhibited additive effects. Conclusions/interpretation Prolonged exposure to glibenclamide activates protein translation in pancreatic beta cells through the calcium-regulated mTOR, PKA and MEK signalling pathways. The observed intercellular differences in translation activation are proposed as underlying mechanism for functional heterogeneity in the pancreatic beta cell population.

Keywords Beta cell - Diabetes - Glibenclamide - Insulin . Islet $\cdot$ Pancreas

$\begin{array}{ll}\text { Abbreviations } \\ \text { 4E-BP1 } & \text { eIF 4E binding protein 1 } \\ \text { eEF } & \text { eukaryotic elongation factor } \\ \text { eIF } & \text { eukaryotic initiation factor } \\ \text { ERK } & \text { extracellular signal-regulated kinase } \\ \text { MEK } & \text { mitogen-activated protein kinase/ERK kinase } \\ \text { mTOR } & \text { mammalian target of rapamycin } \\ \text { PKA } & \text { protein kinase A } \\ \text { PKB } & \text { protein kinase B } \\ \text { PKC } & \text { protein kinase C } \\ \text { rpS6 } & \text { ribosomal protein S6 }\end{array}$

\section{Introduction}

In vitro studies have shown that the normal pancreatic beta cell population exhibits intercellular differences that are 
functionally relevant, in particular for generating its doseresponse curves to glucose [1]. The intercellular differences in glucose sensitivity can be altered by culture at low or high glucose concentrations with subsequent changes in functional responsiveness [2]. This form of regulation also occurs in vivo as was recently shown in glibenclamidetreated rats [3]. A 2 day treatment with this sulfonylurea drug recruited a beta cell subpopulation into an elevated and sustained basal insulin synthetic activity and thus influenced the shape of the subsequent glucose doseresponse curve [3]. The glibenclamide-recruited beta cells were degranulated, indicating that they had also been activated for insulin secretion [3]. Glibenclamide induced similar effects when administered to beta cell cultures for $24 \mathrm{~h}$ but not for $2 \mathrm{~h}$. The elevated rate of insulin synthesis was not associated with an increase in insulin mRNA content [3], which was different from the studies of Yamato et al. $[4,5]$ showing enhanced insulin gene expression in rat islets following exposure to glibenclamide. It appeared to involve a calcium-dependent activation of translation; it was not seen at low extracellular calcium concentrations or in the presence of the calcium channel blocker verapamil or of the translation inhibitor cycloheximide [3]. Taken together, these observations indicate that the functional responsiveness of the pancreatic beta cell population at a particular time is influenced by the translational activity of the cells during the preceding day. They also demonstrate that glibenclamide, which is used for its acute stimulatory effect on insulin release, exerts additional effects after chronic exposure. In this regard, it was previously shown by Guiot et al. [6] that glibenclamide-treatment in vivo for 1 to 2 weeks increased pancreatic beta cell proliferation and beta cell mass in rats, although the mechanism was not addressed. Kwon et al. [7, 8] recently showed glibenclamideinduced calcium-dependent activation of mammalian target of rapamycin (mTOR) at basal glucose $(3 \mathrm{mmol} / \mathrm{l})$ and extended it to the ability of glibenclamide to stimulate mTOR-mediated DNA synthesis and cell cycle progression. Although it is known that mTOR signalling plays important roles in growth factor- and amino acid-induced protein translation $[9,10]$, it is unclear whether it is also involved in glibenclamide-induced activation of translation. The present study investigates the mechanisms of the glibenclamideinduced translation activation. Protein translation is controlled by (de)phosphorylation of eukaryotic initiation factors (eIFs) and/or eukaryotic elongation factors (eEFs), which have been shown to regulate translation in many cell types [9-16] following diverse signalling pathways, including calcium, $\mathrm{mTOR}$, protein kinase $\mathrm{A}$ (PKA), protein kinase $\mathrm{B}(\mathrm{PKB})$, protein kinase $\mathrm{C}(\mathrm{PKC})$ and mitogenactivated protein kinase/extracellular signal-regulated kinase (ERK) kinases (MEKs) [10, 17, 18]. Most of these data, however, were collected during short-term activations, i.e. for minutes or a few hours, and have not been related to subsequent measurements of protein synthesis. Little is known about the existence of these mechanisms in beta cells, in particular with respect to their role in recruiting beta cells over a $24 \mathrm{~h}$ period into a higher state of biosynthetic activity. We selected four initiation/elongation factors, i.e. eIF2 $\alpha$, eIF 4E binding protein 1 (4E-BP1), ribosomal protein S6 (rpS6) and eEF2, and examined whether $24 \mathrm{~h}$ glibenclamide exposure activated these factors in parallel to bringing the cells into a state of sustained basal protein synthetic activity as reflected during a subsequent $1 \mathrm{~h}$ incubation in the absence of the drug. After finding that this was indeed the case, we investigated which signalling pathways were involved in the glibenclamide-induced translation activation by adding pathway-inhibitors to the $24 \mathrm{~h}$ culture period and assessing effects on the phosphorylation state of the translation factors as well as on basal protein synthetic activity during the subsequent $1 \mathrm{~h}$ assay. Microscopic identification of beta cells with phosphorylated rpS6 showed that only a subpopulation of beta cells had been activated, providing mechanistic support for the concept that the beta cell population is functionally heterogeneous.

\section{Methods}

Preparation and culture of purified rat beta cells Adult male Wistar rats were bred according to Belgian regulations on animal welfare. Pancreatic islets were isolated by collagenase digestion as described previously [19]. Islets were further dissociated into single cells in calcium-free medium containing trypsin and DNase [19]. Single beta cells were purified by autofluorescence-activated sorting, using cellular light-scatter and flavin adenine dinucleotideautofluorescence as discriminating parameters [19].

Purified beta cells were suspended in Lux dishes (Miles, Naperville, IL, USA) containing $3 \mathrm{ml}$ serum-free culture medium [3], reaggregated for $2 \mathrm{~h}$ in a rotatory shaking incubator (Braun, Melsungen, Germany) and then further cultured under static conditions in standard $\mathrm{CO}_{2}$ incubator $\left(37^{\circ} \mathrm{C}, 95 \%\right.$ air $\left./ 5 \% \mathrm{CO}_{2}\right)$. Culture medium was Ham's F10 (Invitrogen, Paisley, UK) containing $6 \mathrm{mmol} / \mathrm{l}$ glucose, supplemented with $0.075 \mathrm{mg} / \mathrm{ml}$ penicillin, $0.1 \mathrm{mg} / \mathrm{ml}$ streptomycin, $2 \mathrm{mmol} / \mathrm{l}$ L-glutamine, $0.5 \%$ (wt/vol.) bovine serum albumin pretreated with charcoal (BSA, fraction V; Sigma Chemical, St Louis, MO, USA) and calcium to $2 \mathrm{mmol} / \mathrm{l}$. After overnight culture, rat beta cells were further cultured for 1 or $24 \mathrm{~h}$ at $6 \mathrm{mmol} / 1$ glucose with $4 \mu \mathrm{mol} / \mathrm{l}$ glibenclamide (MP Biomedicals, Eschwege, Germany) or for $24 \mathrm{~h}$ with different concentrations of the drug $(0.04$ to $4 \mu \mathrm{mol} / \mathrm{l})$. In one series of experiments, inhibitors were added $1 \mathrm{~h}$ before $24 \mathrm{~h}$ glibenclamide treatment, i.e. mTOR inhibitor rapamycin (25 nmol/l; Cell Signaling Technology, 
Danvers, MA, USA), the calcium channel blocker verapamil (10 $\mu \mathrm{mol} / 1$; Knoll, Brussels, Belgium), PKA inhibitor 8BrRp-isomer (Rp-8-Br-cAMP; $100 \mu \mathrm{mol} / \mathrm{l}$; Biolog, Bremen, Germany), PKC inhibitor GF109203X (0.1 to $10 \mu \mathrm{mol} / \mathrm{l}$; Sigma) and MEK inhibitor U0126 (40 $\mu \mathrm{mol} / \mathrm{l}$; Cell Signaling Technology) and PD98059 $(50 \mu \mathrm{mol} / \mathrm{l}$; Calbiochem, San Diego, CA, USA). At the end of culture, cells were analysed for protein synthesis and abundance of translation factors. Beta cells were also cultured as a single unit in polylysine-coated chamber slides (Nalge Nunc International, Rochester, NY, USA) for subsequent immunocytochemical analysis. These culture conditions did not affect beta cell survival in the present study (Q. Wang and Z. Ling, unpublished observation), although a recent report showed that glibenclamide induced beta cell apoptosis in cultured human islets [20].

Protein synthesis and abundance The rate of protein synthesis was measured in beta cell aggregates following their culture for $24 \mathrm{~h}$ as described above. Samples of $3 \times 10^{4}$ cells were incubated for $1 \mathrm{~h}$ in Ham's F10 medium at 0 or $10 \mathrm{mmol} / \mathrm{l}$ glucose without any drugs or inhibitors added, but in presence of $1.85 \mathrm{MBq} \mathrm{L}-\left[3,5-{ }^{3} \mathrm{H}\right]$ tyrosine (GE Healthcare, Chalfont St Giles, UK). Basal and glucoseinducible protein and proinsulin synthesis were determined as previously described [21].

Protein abundance was analysed in beta cell aggregates following the $24 \mathrm{~h}$ culture period or following the subsequent $1 \mathrm{~h}$ incubation. Samples of $2 \times 10^{5}$ to $3 \times 10^{5}$ cells were run on a $12 \%$ SDS-polyacrylamide gel before protein transfer on a nitrocellulose membrane and incubation with antibodies against: 4E-BP1 (Santa Cruz, Santa Cruz, CA, USA), total eIF $2 \alpha$, phospho-eIF2 $\alpha$ (Ser51), total rpS6, phospho-rpS6 (Ser235/236), total eEF2, phosphoeEF2 (Thr56), phospho-PKB/Akt (Ser473) and phosphoPKC pan ( $\beta$ II Ser660) (all from Cell Signaling Technology), as well as phospho-p42/44 ERK(Thr202/Tyr204) (New England Biolabs, Ipswich, MA, USA) and actin (Santa Cruz). Horseradish peroxidase-linked anti-rabbit, antimouse or anti-goat Ig (1:1,000; Amersham, Little Chalfont, UK) were used as second antibodies and peroxidase activities were detected by enhanced chemiluminescence (Amersham). Intensities of bands were quantified by Scion image software (Scion, Frederick, MD, USA), expressed in arbitrary units of optical density and normalised for actin intensity in the same blot.

Formaldehyde-fixed single beta cells were stained for DNA using Hoechst33342, for phospho-rpS6 and insulin (Biotrend, Cologne, Germany) using, respectively, Cy3and Alexa Fluor488-labelled second antibodies (Invitrogen, Eugene, OR, USA). Fluorescence intensities were analysed by BD Pathway Bioimager using Attovision software (BD Biosciences, Rockville, MD, USA).
Statistical analysis Results were expressed as mean \pm SEM. Statistical significance of differences was calculated by ANOVA, using Newman-Keuls multiple comparison test.

\section{Results}

Glibenclamide-induced stimulation of protein translation in rat beta cells Consistent with our previous observation [3], short-term culture ( 1 to $8 \mathrm{~h}$ ) of rat beta cells with insulinreleasing concentrations of glibenclamide $(4 \mu \mathrm{mol} / \mathrm{l}) \mathrm{did}$ not influence their subsequent rates of protein synthesis (data not shown), while a $24 \mathrm{~h}$ exposure did. When cells treated for $24 \mathrm{~h}$ with glibenclamide were incubated for $1 \mathrm{~h}$ in a glucosefree medium, their total protein and insulin synthesis (defined as 'basal') was four- to sixfold higher than that in control cells cultured without the drug (Table 1). This difference was not observed when the $1 \mathrm{~h}$ incubation was conducted at $10 \mathrm{mmol} / \mathrm{l}$ glucose (Table 1 ), a concentration that is known to maximally stimulate protein and insulin synthesis [2, 21, 22]. Glibenclamide-pretreatment thus recruits beta cells into a higher basal activity that is maintained in absence of extracellular glucose; this effect does not increase the insulin-synthesising capacity at maximal glucose stimulation.

Culture with glibenclamide altered the phosphorylation state of the four selected translation factors. As for its effect on basal synthetic activity, these influences also required a longer exposure time to glibenclamide ( $24 \mathrm{~h}$ instead of $1 \mathrm{~h}$; Fig. 1). They were maintained during a subsequent $1 \mathrm{~h}$ incubation in absence of the drug and in a glucose-free medium (Fig. 2). At both time points, phosphorylation of rpS6 and of 4E-BP1 was associated with dephosphorylation of eEF2 and eIF $2 \alpha$ (Figs 1, 2). The 4E-BP1 phosphorylation appeared in the shift of the non-phosphorylated $\alpha$-band to the highly phosphorylated $\gamma$-band (Figs $1 b, 2 b$ ). In terms of total protein abundance, a rise in $\mathrm{rpS6}$ was measured, but the three others remained unchanged (Fig. 2). All changes were also seen when the $1 \mathrm{~h}$ incubation occurred at $10 \mathrm{mmol} / \mathrm{l}$ glucose, except for 4E-BP1 (Fig. 2).

The glibenclamide concentration used in this study is similar to that of previous in vitro studies [23-25]. It is, however, significantly higher than that in patients (below $0.4 \mu \mathrm{mol} / 1)[26,27]$. We have repeated representative experiments at lower concentrations $(0.04$ and $0.4 \mu \mathrm{mol} / \mathrm{l})$ and found similar effects (Fig. 3). Culture for $24 \mathrm{~h}$ with $0.04 \mu \mathrm{mol} / 1$ glibenclamide increased the subsequent basal protein synthetic activity (Fig. 3a), phosphorylation of rpS6 and dephosphorylation of eIF $2 \alpha$ and eEF2 (Fig. 3b).

Signalling pathways involved in glibenclamide-induced protein translation The calcium channel blocker verapamil 
Table 1 Protein and insulin biosynthetic activity following $24 \mathrm{~h}$ culture with glibenclamide

\begin{tabular}{|c|c|c|c|c|}
\hline \multirow[t]{2}{*}{ Cell preparations } & \multicolumn{2}{|c|}{ Total protein synthesis $\left(\mathrm{dpm}\right.$ cell $\left.{ }^{-1} \mathrm{~h}^{-1}\right)$} & \multicolumn{2}{|c|}{ Insulin synthesis $\left(\mathrm{dpm}\right.$ cell $\left.^{-1} \mathrm{~h}^{-1}\right)$} \\
\hline & $0 \mathrm{mmol} / 1$ glucose & $10 \mathrm{mmol} / 1$ glucose & $0 \mathrm{mmol} / 1$ glucose & $10 \mathrm{mmol} / 1$ glucose \\
\hline \multicolumn{5}{|l|}{ Experiment 1} \\
\hline Control & $0.8 \pm 0.1$ & $5.5 \pm 0.4$ & $0.2 \pm 0.02$ & $3.3 \pm 0.4$ \\
\hline Glibenclamide & $3.1 \pm 0.5^{\mathrm{a}}$ & $5.7 \pm 0.4$ & $1.3 \pm 0.3^{\mathrm{b}}$ & $2.8 \pm 0.4$ \\
\hline Verap & $0.6 \pm 0.05$ & $4.7 \pm 0.4$ & $0.2 \pm 0.03$ & $3.5 \pm 0.5$ \\
\hline Glib + verapamil & $0.9 \pm 0.2^{\mathrm{d}}$ & $4.4 \pm 0.9$ & $0.2 \pm 0.1^{\mathrm{d}}$ & $3.3 \pm 0.6$ \\
\hline Rapamycin & $0.6 \pm 0.1$ & $4.3 \pm 0.4$ & $0.2 \pm 0.03$ & $2.9 \pm 0.3$ \\
\hline Glib + Rapamycin & $1.3 \pm 0.1^{\mathrm{d}}$ & $4.3 \pm 0.4$ & $0.6 \pm 0.1^{\mathrm{d}}$ & $2.7 \pm 0.5$ \\
\hline \multicolumn{5}{|l|}{ Experiment 2} \\
\hline Control & $0.8 \pm 0.1$ & $4.0 \pm 0.5$ & $0.2 \pm 0.1$ & $2.9 \pm 0.4$ \\
\hline Glibenclamide & $2.4 \pm 0.3^{\mathrm{a}}$ & $4.8 \pm 1.0$ & $1.5 \pm 0.3^{\mathrm{a}}$ & $2.9 \pm 0.3$ \\
\hline PKA inhibitor & $0.6 \pm 0.1$ & $4.1 \pm 0.5$ & $0.2 \pm 0.1$ & $3.0 \pm 0.4$ \\
\hline Glib + PKA inhibitor & $1.2 \pm 0.1^{\mathrm{d}}$ & $3.6 \pm 0.6$ & $0.6 \pm 0.2^{\mathrm{d}}$ & $2.3 \pm 0.5$ \\
\hline \multicolumn{5}{|l|}{ Experiment 3} \\
\hline Control & $0.9 \pm 0.07$ & $5.3 \pm 0.7$ & $0.3 \pm 0.04$ & $3.4 \pm 0.3$ \\
\hline Glibenclamide & $3.8 \pm 0.6^{\mathrm{a}}$ & $5.6 \pm 0.7$ & $1.9 \pm 0.2^{\mathrm{a}}$ & $3.8 \pm 1.0$ \\
\hline U0126 & $0.7 \pm 0.07$ & $5.0 \pm 0.9$ & $0.2 \pm 0.04$ & $3.6 \pm 0.3$ \\
\hline Glib + U0126 & $2.6 \pm 0.2^{\mathrm{b}, \mathrm{c}}$ & $5.1 \pm 0.6$ & $1.3 \pm 0.1^{\mathrm{a}, \mathrm{d}}$ & $2.7 \pm 0.2$ \\
\hline
\end{tabular}

Purified rat beta cells were cultured for $24 \mathrm{~h}$ at $6 \mathrm{mmol} / \mathrm{l}$ glucose with or without: $4 \mu \mathrm{mol} / 1$ glibenclamide (Glib), $10 \mu \mathrm{mol} / 1 \mathrm{verapamil}, 25 \mathrm{nmol} /$ 1 rapamycin, $100 \mu \mathrm{mol} / 1$ PKA inhibitor Rp-8-Br-cAMP, $40 \mu \mathrm{mol} / 1 \mathrm{MEK}$ inhibitor U0126. Total protein and insulin synthesis was measured during a subsequent $1 \mathrm{~h}$ incubation at 0 or $10 \mathrm{mmol} / \mathrm{l}$ glucose in absence of these compounds

Data represent means \pm SEM of eleven, six and six independent experiments accordingly

${ }^{\mathrm{a}} p<0.001,{ }^{\mathrm{b}} p<0.05$ for differences between conditions with and without glibenclamide at the same glucose concentration

${ }^{\mathrm{c}} p<0.05,{ }^{\mathrm{d}} p<0.01$ for differences with and without inhibitor in the presence of glibenclamide and at the same glucose concentration

prevented glibenclamide-induced protein and insulin synthesis (Table 1) as described previously [3] and blocked glibenclamide-induced phosphorylation of $\mathrm{rpS} 6$ and 4EBP1 (Fig. 4a,b), as well as glibenclamide-induced dephosphorylation of eEF2 and eIF2 $\alpha$ (Fig. $4 c, d$ ). We next

a

Time $\quad \frac{\text { Glib }}{-1 \mathrm{~h} 24 \mathrm{~h}} \quad \frac{\text { Glib }}{-1 \mathrm{~h} 24 \mathrm{~h}}$

p-rpS6

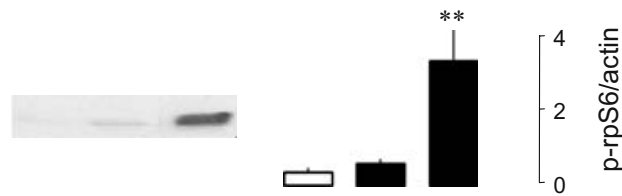

b

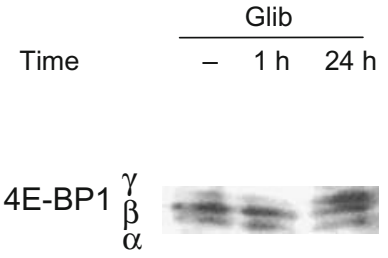

d
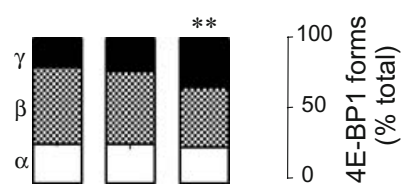

Fig. 1 Phosphorylation of translation factors in cultured beta cells. Purified rat beta cells were cultured for $24 \mathrm{~h}$ at $6 \mathrm{mmol} / \mathrm{l}$ glucose without or with $4 \mu \mathrm{mol} / 1$ glibenclamide (Glib), which was present during the entire $24 \mathrm{~h}$ period or was added during the last $1 \mathrm{~h}$ of culture. The abundance of translation factors a p-rpS6, b 4E-BP1, c p-eEF2 and $\mathbf{d}$ p-eIF2 $\alpha$ was analysed by western blot using specific antibodies (see the Methods). Band intensities (b) of $\alpha$ (white bars), $\beta$ examined the involvement of known calcium-driven pathways in the activation of translation factors and the recruitment of beta cells into a sustained protein synthetic activity.

The glibenclamide-induced activation of translation appears to be partly mediated by mTOR, as addition of

C

$$
\text { Time }
$$
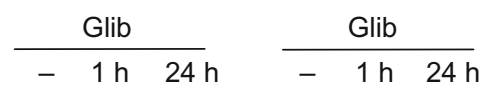

p-eEF2
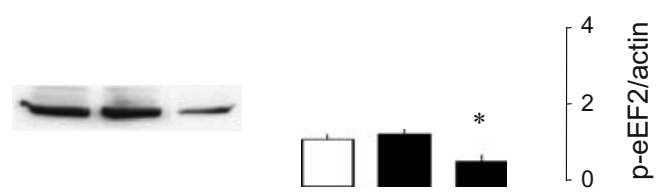

Time
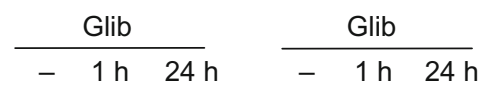

p-elF2 $\alpha$
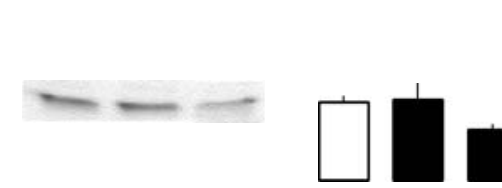

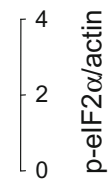

(grey bars), $\gamma$ (black bars) were expressed as \% of total intensity $(\alpha+\beta+\gamma)$; those of a p-rpS6, c p-eEF2 and d p-eIF2 $\alpha$ were normalised for the corresponding actin intensity. Data represent means \pm SEM of three to seven independent experiments. $* p<0.05$, $*^{*} p<0.01$, for difference from control; $p$ values for 4E-BP1 (b) are for differences between conditions in $\gamma$-bands 
a

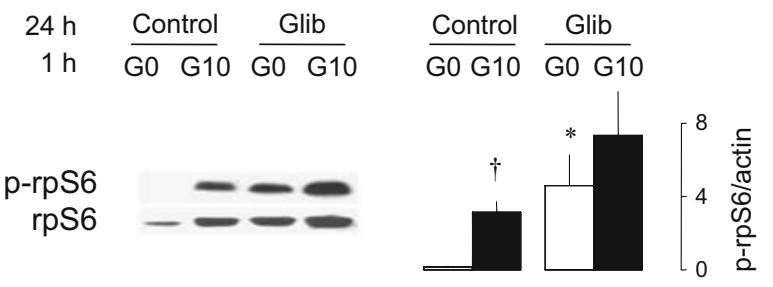

C

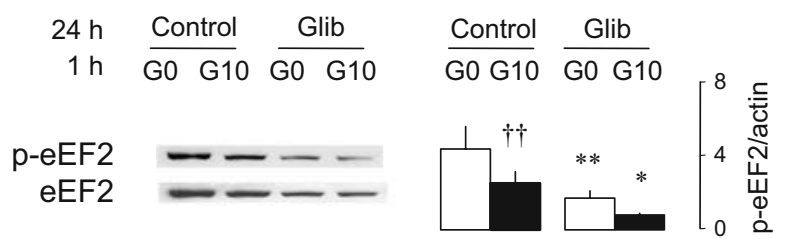

Fig. 2 Abundance and phosphorylation of translation factors following $24 \mathrm{~h}$ culture with glibenclamide. Purified rat beta cells were cultured for $24 \mathrm{~h}$ at $6 \mathrm{mmol} / \mathrm{l}$ glucose without (Control) or with $4 \mu \mathrm{mol} / \mathrm{l}$ glibenclamide (Glib), followed by a $1 \mathrm{~h}$ incubation at 0 (G0) or $10(\mathrm{G} 10) \mathrm{mmol} / \mathrm{l}$ glucose without the compounds of pretreatment. The abundance of translation factors a rpS6, b 4E-BP1, c eEF2 and d

the mTOR inhibitor rapamycin $(25 \mathrm{nmol} / \mathrm{l})$ decreased the glibenclamide-induced stimulation of protein and insulin synthesis (Table 1) and the associated phosphorylation of rpS6 and 4E-BP1 (Fig. 4a,b); it did not, however, affect glibenclamide-induced dephosphorylation of eEF2 and eIF2 $\alpha$ (Fig. $4 c, d)$. The mTOR activation can in part result from a glibenclamide-induced PKB phosphorylation, which was also completely prevented by verapamil (Fig. 4e), but not by rapamycin. It is unlikely that the mTOR activation is caused by locally released insulin, since $24 \mathrm{~h}$ culture of beta cells with $200 \mathrm{nmol} / \mathrm{l}$ insulin did not affect the rates of insulin synthesis or the phosphorylation of 4E-BP1 and rpS6 (data not shown).

The glibenclamide effects were also counteracted by the PKA inhibitor Rp-8-Br-cAMP. This agent suppressed the rates of protein and insulin synthesis by 50 to $60 \%$ (Table 1) and partially prevented phosphorylation of $\mathrm{rpS} 6$ and 4EBP1 (Fig. 5a,b), as well as dephosphorylation of eEF2 (Fig. 5c). Since the PKA inhibitor also inhibited glibenclamide-induced PKB activation (Fig. 5e), the influence of PKA on glibenclamide-induced translation appears at least in part to be mediated through PKB and mTOR activation. The existence of an mTOR-independent PKA effect is supported by the fact that glibenclamide-induced insulin synthesis was only partially inhibited by an mTOR or a PKA inhibitor (by $56 \pm 3$ and $62 \pm 6 \%$ respectively; Table 1), whereas a stronger suppression was seen when both inhibitors were combined ( $86 \pm 1 \%$ reduction). It was nevertheless noticed that in the presence of both inhibitors, glibenclamide-induced insulin synthesis still produced twofold more insulin than in control cells, suggesting the involvement of yet another pathway. PKC does not appear
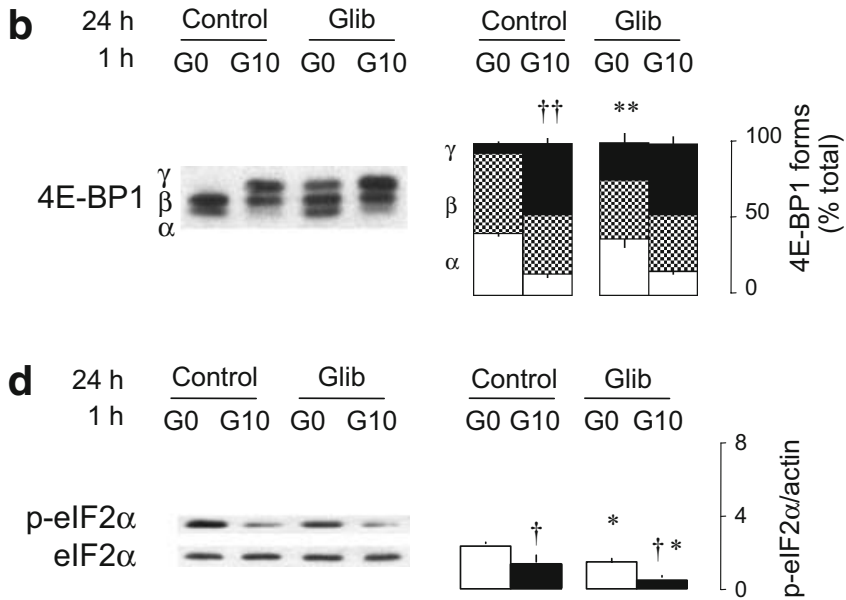

eIF $2 \alpha$ was analysed as described for Fig. 1. Data represent means \pm SEM of three or four independent experiments. ${ }^{*} p<0.05,{ }^{*} p<0.01$, for differences between conditions with or without Glib at the same glucose concentration; ${ }^{\dagger} p<0.05,{ }^{\dagger \dagger} p<0.01$ for difference with or without $10 \mathrm{mmol} / 1$ glucose in absence or presence of Glib; $p$ values for 4E-BP1 (b) are for differences between conditions in $\gamma$-bands

to be involved, since its inhibitor, GF109203X, had no effect on glibenclamide-induced protein synthesis (data not shown). This is also consistent with the observation that $24 \mathrm{~h}$ culture with glibenclamide did not influence phosphorylation of calcium-dependent PKCs (data not shown).

MEK/ERK signalling may qualify as an additional calcium-dependent pathway. Addition of the MEK-inhibitor U0126 (40 $\mu \mathrm{mol} / \mathrm{l})$ caused a 30 to $35 \%$ inhibition of glibenclamide-induced protein and insulin synthesis (Table 1), an effect that was additive to that of rapamycin and the PKA inhibitor (data not shown). However, the U0126-induced inhibition was not associated with an inhibition of the glibenclamide-induced phosphorylation of rpS6 and 4E-BP1 or dephosphorylation of eEF2 and eIF-2 $\alpha$ (Fig. 6d). It was

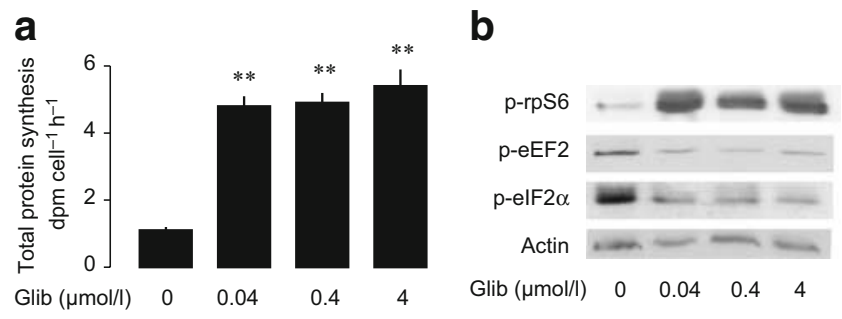

Fig. 3 Effects of different concentrations of glibenclamide pretreatment on basal protein synthesis and phosphorylation of translation factors. Purified rat beta cells were cultured for $24 \mathrm{~h}$ at $6 \mathrm{mmol} /$ 1 glucose without or with different concentrations of glibenclamide (Glib). a Total protein synthesis was measured during a subsequent $1 \mathrm{~h}$ incubation in absence of glucose and of glibenclamide. Data represent means \pm SEM of three independent experiments. ${ }^{* *} p<0.01$ for differences between conditions with or without gibenclamide. b The abundance of p-rpS6, p-eIF2 $\alpha$ and p-eEF2 was analysed as described for Fig. 1. Data are representative of two independent experiments 
noticed that glibenclamide for $24 \mathrm{~h}$ increased the phosphorylation of ERK-1 and ERK-2 twofold (Fig. 6a-c), an effect that was completely blocked by verapamil (Fig. 6a-c). The MEK-inhibitor U0126 (40 $\mu \mathrm{mol} / \mathrm{l})$ reduced phospho-ERKs irrespective of the presence of glibenclamide $(70 \pm 14$ and $60 \pm$ $10 \%$ inhibition of ERK-1 and ERK-2 in the absence of glibenclamide respectively versus $51 \pm 17$ and $40 \pm 12 \%$ in its presence; $n=4$; Fig. $6 \mathrm{a}-\mathrm{c}$ ) and was therefore considered to suppress constitutively phosphorylated ERKs rather than glibenclamide-induced phosphorylation. The latter was also not blocked by another MEK inhibitor, PD98059 (data not shown).

Intercellular differences in translation activation form the basis for functional heterogeneity in the pancreatic beta cell population An antibody to the phosphorylated form of rpS6 was used to investigate whether the glibenclamideinduced activation of translation factors could be detected by immunocytochemistry and whether it also occurred in a beta cell subpopulation, similar to the previously reported recruitment of cells into an elevated biosynthetic activity. Phospho-rpS6-positive cells were detectable after $24 \mathrm{~h}$ culture with glibenclamide and clearly corresponded to a

a $24 \mathrm{~h} \frac{\text { NO }}{\text { C Glib }} \frac{\text { Rapa }}{\text { C Glib }} \frac{\text { Verap }}{\text { C Glib }} \frac{\text { NO }}{\text { C Glib }} \frac{\text { Rapa }}{\text { C Glib }} \frac{\text { Verap }}{\text { C Glib }}$

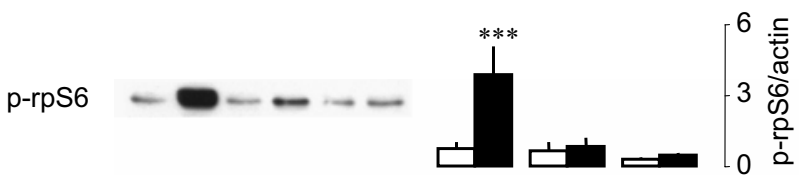

b

$24 \mathrm{~h} \quad \frac{\text { NO }}{\text { C Glib C Glib }} \frac{\text { Rapa }}{\text { C Glib }} \frac{\text { Norap }}{\text { C Glib }} \frac{\text { Rapa }}{\text { C Glib }} \frac{\text { Verap }}{\text { C Glib }}$

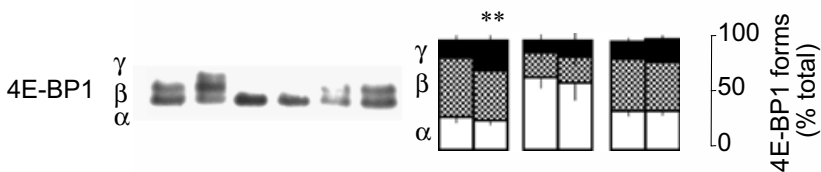

C

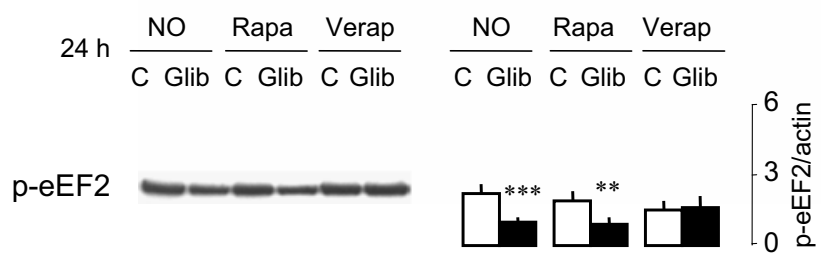

Fig. 4 Effects of rapamycin and verapamil on glibenclamide-induced activation of translation factors. Purified rat beta cells were cultured for $24 \mathrm{~h}$ at $6 \mathrm{mmol} / \mathrm{l}$ glucose without (C) or with $4 \mu \mathrm{mol} /$ 1 glibenclamide (Glib), in absence (NO) or presence of $25 \mathrm{nmol} /$ 1 rapamycin (Rapa) or $10 \mu \mathrm{mol} / 1$ verapamil (Verap). The abundance of translation factors a p-rpS6, b 4E-BP1, c p-eEF2, d p-eIF2 $\alpha$ and e p- subpopulation ( $38 \pm 2 \%$ strongly positive cells) that was more than fourfold smaller in the control condition $(8 \pm 1 \%$, $p<0.001, n=5$; Fig. 7a). The glibenclamide-induced increase in the number of phospho-rpS6-positive cells was completely blocked by addition of verapamil $(9 \pm 1 \%)$ or of

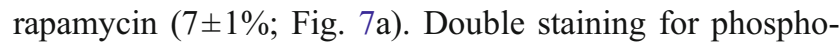
rpS6 and insulin indicated that the phospho-rpS6-positive cells corresponded to beta cells with lower fluorescence intensity for insulin (Fig. 7b,c) and thus to the more degranulated cells that were previously identified as those exhibiting a glibenclamide-induced functional activation.

\section{Discussion}

Sulfonylureas have been used for decades in the treatment of diabetes. Their hypoglycaemic action is attributed to a stimulation of insulin release that rapidly follows the drug's binding to a surface membrane receptor and a subsequent rise in cytoplasmic free calcium concentration [28, 29]. We recently reported that glibenclamide, a second-generation sulfonylurea, also exerts a stimulatory effect on insulin

d

$$
24 \mathrm{~h} \frac{\text { NO }}{\text { C Glib }} \frac{\text { Rapa }}{\text { C Glib }} \frac{\text { Verap }}{\text { C Glib }} \quad \frac{\text { NO }}{\text { C Glib }} \frac{\text { Rapa }}{\text { C Glib }} \frac{\text { Verap }}{\text { C Glib }}
$$
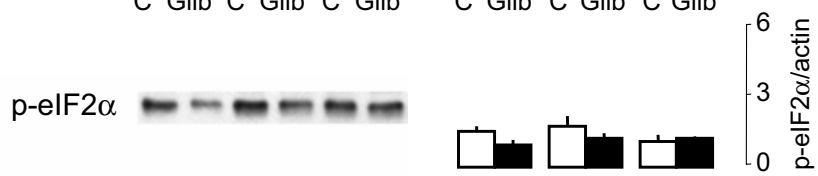

e

$$
24 \mathrm{~h} \frac{\text { NO }}{\text { C Glib }} \frac{\text { Rapa }}{\text { C Glib }} \frac{\text { Verap }}{\text { C Glib }} \frac{\text { NO }}{\text { C Glib }} \frac{\text { Rapa }}{\text { C Glib }} \frac{\text { Verap }}{\text { C Glib }}
$$

p-PKB

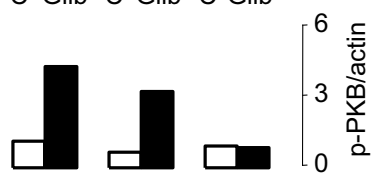

PKB was analysed as described for Fig. 1. Data represent means \pm SEM of five to seven experiments $(\mathbf{a}, \mathbf{b}, \mathbf{c}, \mathbf{d})$ or are representative of two independent experiments (e). ${ }^{*} p<0.01, * * * p<0.001$, for differences between conditions with or without Glib in absence or presence of inhibitors; $p$ values for 4E-BP1 (b) are for differences in $\gamma$-bands between conditions 
synthesis when present over a prolonged period, i.e. beyond $8 \mathrm{~h}$ [3]. Culture with the drug as well as in vivo treatment recruited a subpopulation of beta cells into an elevated and sustained protein synthetic activity. This effect was also calcium-dependent but appeared to involve a translational activity [3]. The present study now shows that glibenclamide activates translation at the steps of initiation and elongation, as evidenced by 4E-BP1 and rpS6 phosphorylation, and eIF $2 \alpha$ and eEF2 dephosphorylation. Furthermore, the rise in total $\mathrm{rpS} 6$ is indicative of an associated increase in ribosome biogenesis. These effects can explain the glibenclamide-induced elevation in the beta cell synthetic activity following prolonged exposure, which is supported by the following evidence. First, the (de)phosphorylation of translation factors followed a similar time course as the increased protein synthetic activity. Second, the translation activation was maintained during subsequent incubations in absence of the drug, as was also the case for the protein synthetic activity. Third, the increased translational activity was located in a subpopulation of beta cells, more particularly those with lower insulin content that represented the cells with increased functional responses. By identifying this

a

$24 \mathrm{~h} \frac{\mathrm{NO}}{\mathrm{C} \text { Glib }} \frac{\mathrm{PKAi}}{\mathrm{C} \text { Glib }} \quad \frac{\mathrm{NO}}{\mathrm{C} \text { Glib }} \frac{\mathrm{PKAi}}{\mathrm{C} \mathrm{Glib}}$

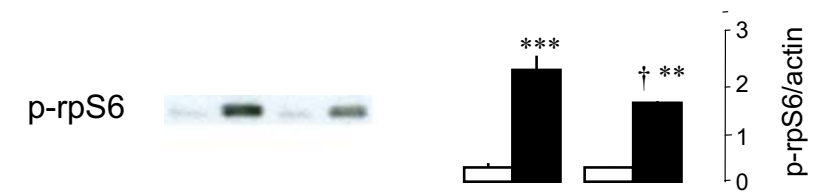

b

$24 \mathrm{~h} \frac{\mathrm{NO}}{\mathrm{C} \text { Glib }} \frac{\text { PKAi }}{\text { C Glib }} \quad \frac{\text { NO }}{\text { C Glib }} \frac{\text { PKAi }}{\text { C Glib }}$
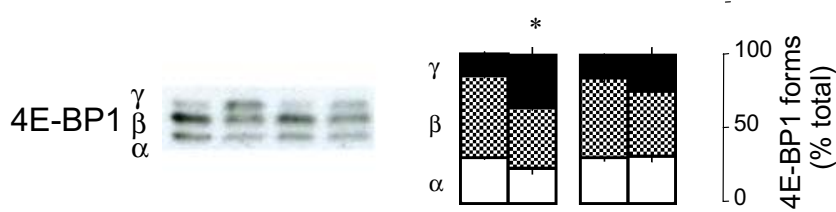

C

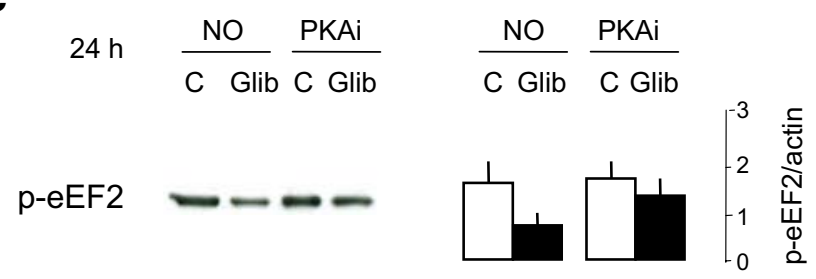

Fig. 5 Effects of PKA inhibitor on glibenclamide-induced activation of translation factors. Purified rat beta cells were cultured for $24 \mathrm{~h}$ at $6 \mathrm{mmol} / 1$ glucose without (C) or with $4 \mu \mathrm{mol} / 1$ glibenclamide (Glib), in absence (NO) or presence of $100 \mu \mathrm{mol} / 1$ PKA inhibitor Rp-8-BrcAMP (PKAi). The abundance of translation factors a p-rpS6, b 4E$\mathrm{BP} 1, \mathbf{c}$ p-eEF2, d p-eIF2 $\alpha$ and e p-PKB was analysed as described for subpopulation under the microscope, the immunostaining for phospho-rpS6 not only supported the concept of a functional heterogeneity in the beta cell population, but also provided evidence that intercellular differences in functional responses can be caused by differences in the state of activation of translation factors. Since the translational activity was shown to be regulated by chronic or sustained influences, it can be concluded that signs of functional heterogeneity during an acute stimulation may well reflect influences of a chronic nature, which have prevailed in prior days.

It is known that prolonged exposure to glibenclamide maintains high intracellular calcium levels [30]. Several calcium dependent signalling pathways appear now to be responsible for activation of translation and subsequent protein synthesis in beta cells under sustained glibenclamide influence. They were identified by examining the effects of pathway inhibitors on both functions. Partial suppression was observed in the presence of the mTOR inhibitor rapamycin, the PKA inhibitor Rp-8-Br-cAMP and the MEK inhibitor U0126. None of these inhibitors completely blocked the glibenclamide effects, as the

d
$24 \mathrm{~h}$

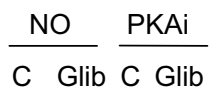

p-elF2 $\alpha$

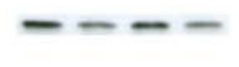

e

$24 \mathrm{~h}$

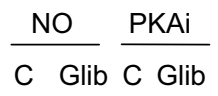

$\mathrm{p}-\mathrm{PKB}$ $\frac{\text { NO }}{\text { C Glib }} \frac{\text { PKAi }}{\text { C Glib }}$
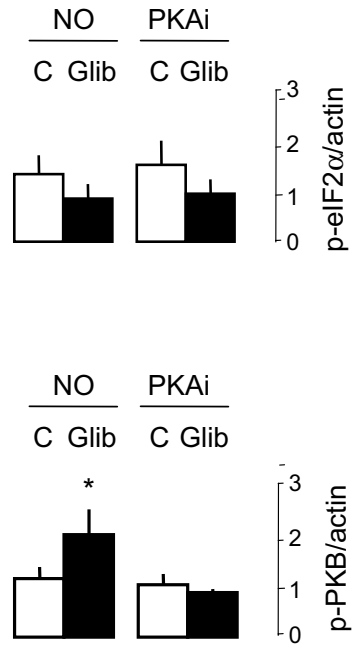

Fig. 1. Data represent means \pm SEM of three independent experiments. ${ }^{*} p<0.05,{ }^{* *} p<0.01,{ }^{* * *} p<0.001$, for differences between conditions with or without Glib in absence or presence of inhibitor; ${ }^{\dagger} p<0.05$ for difference with or without PKAi, in absence or presence of Glib; $p$ values for 4E-BP1 (b) are for differences in $\gamma$-bands between conditions 
calcium channel blocker verapamil did, but a combination of two compounds was additive, which is indicative of a regulation through more than one pathway. This diversity allows integration of signals from multiple extracellular regulators into a balanced activation of various translational operators and an adaptation of the protein synthetic activity.

The higher insulin synthesis by beta cells following prolonged exposure to glibenclamide was partially achieved through an mTOR-stimulated activation of the translational regulators 4E-BP1 and rpS6. The phosphorylation of both proteins was completely suppressed by the MTOR inhibitor rapamycin, resulting in partial inhibition of protein synthesis. As in other cell types and experimental conditions, the glibenclamide activation of mTOR can be explained by the rise in intracellular calcium [31, 32], which acts through phosphorylation of PKB [33] and activation of PKA [8] or an as yet undefined intermediate. Glibenclamide induced phosphorylation of $\mathrm{PKB}$, a well-known upstream kinase of mTOR [10, 34, 35]; this effect was not influenced by rapamycin, but was completely abolished by verapamil and the PKA inhibitor. It was, however, noticed that the PKA inhibitor only partially suppressed phosphorylation of 4EBP1 and rpS6, while rapamycin and verapamil caused complete suppression. The PKA-mediated PKB phosphorylation is therefore not the sole activating pathway of mTOR in glibenclamide-treated beta cells, supporting the

a

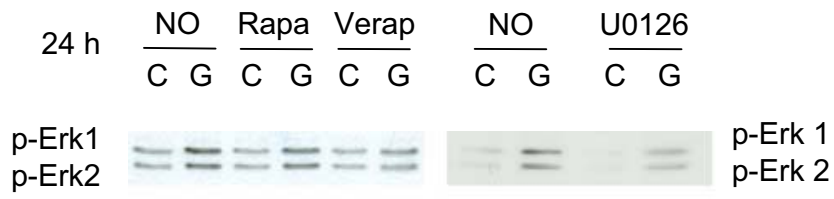

b

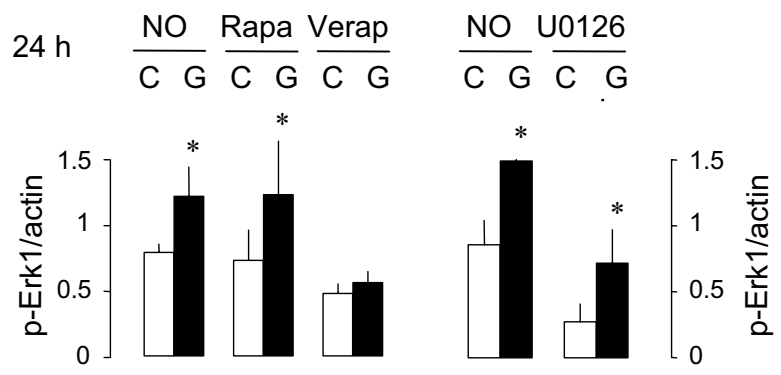

Fig. 6 Effects of MEK/ERK pathway on glibenclamide-induced activation of translation factors. Purified rat beta cells were cultured for $24 \mathrm{~h}$ at $6 \mathrm{mmol} / 1$ glucose without (C) or with $4 \mu \mathrm{mol} / 1$ glibenclamide $(\mathrm{G})$ in absence (NO) or presence of following inhibitors: $25 \mathrm{nmol} / \mathrm{l}$ rapamycin (Rapa), $10 \mu \mathrm{mol} / 1$ verapamil (Verap), $40 \mu \mathrm{mol} / 1 \mathrm{MEK}$ inhibitor U0126. a Abundance of p-ERK1/2. b, c Band intensities of co-existence of a calcium-dependent and PKB-independent activation of mTOR.

Glibenclamide-induced protein translation also appears to be stimulated through mTOR-independent but calciumdependent pathways involving dephosphorylation of the initiation factor eIF $2 \alpha$ and the elongation factor eEF2. An mTOR independency of eIF $2 \alpha$ (de)phosphorylation has been noticed in other cells [36, 37]. The glibenclamideinduced dephosphorylation of eEF2 was almost completely prevented by the PKA inhibitor, indicating the existence of an additional way in which PKA stimulates translation. In other cell types and conditions, calcium and PKA were reported to exert different effects, i.e. activation of eEF2 kinase and inactivation eEF2, thus switching off elongation $[15,38-40]$. This is not necessarily a discrepancy, as it may be related to the respective specificities in the functional regulation of cells. In beta cells, the translational activation following a sustained rise in calcium and PKA is functionally relevant, as it should compensate for the sustained increase in insulin release under this condition [41-43].

Our data suggest a role for (an) as yet unidentified translation factor(s) in glibenclamide-induced translation activation, in addition to 4E-BP1, rpS6, eIF2 $\alpha$ and eEF2. Indeed, incubations with the MEK inhibitor U0126 reduced glibenclamide-induced protein synthesis by $35 \%$, without affecting the (de)phosphorylation of these four proteins. It

\section{C}

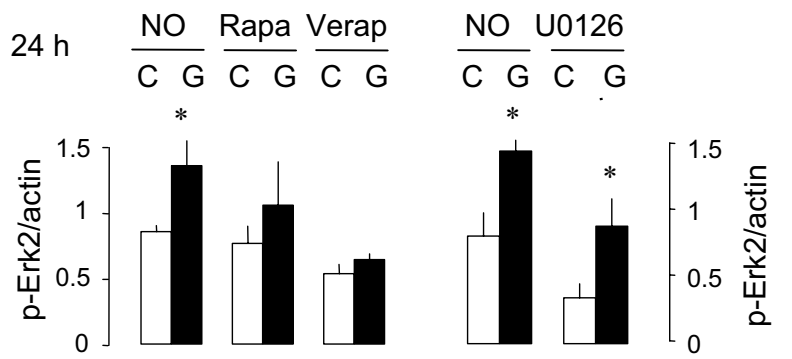

d

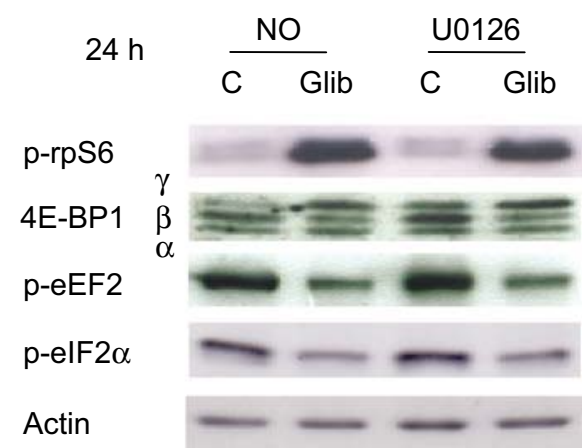

p-ERK1/2 were normalised for the corresponding actin intensity. Data represent means \pm SEM of four to five independent experiments. $* p<0.05$ for differences between conditions with or without Glib in absence or presence of inhibitor. d Abundance of p-rpS6,4E-BP1, p-eEF 2 and p-eIF $2 \alpha$ is representative of three independent experiments 
a

\section{Control}
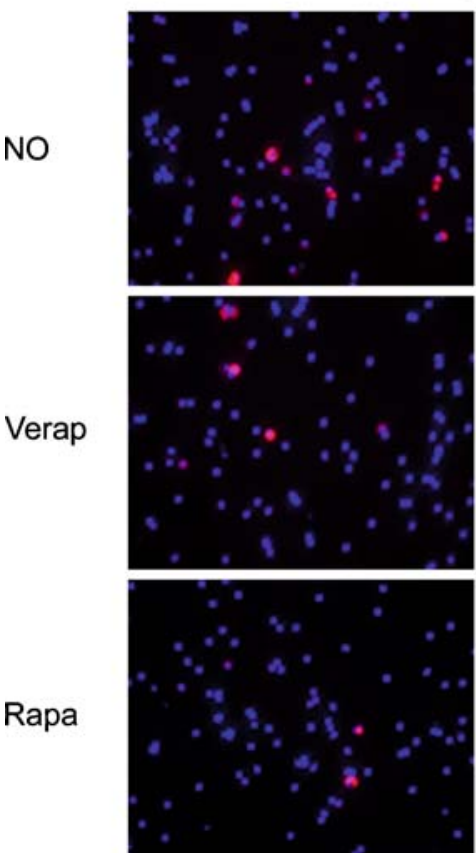

Rapa

Verap p-rpS6
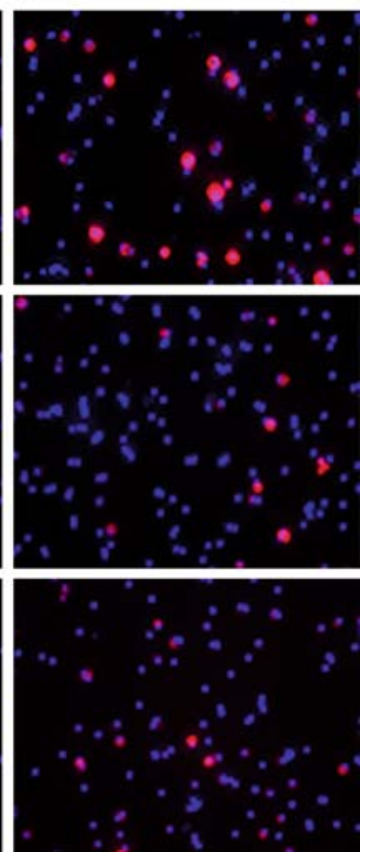

b
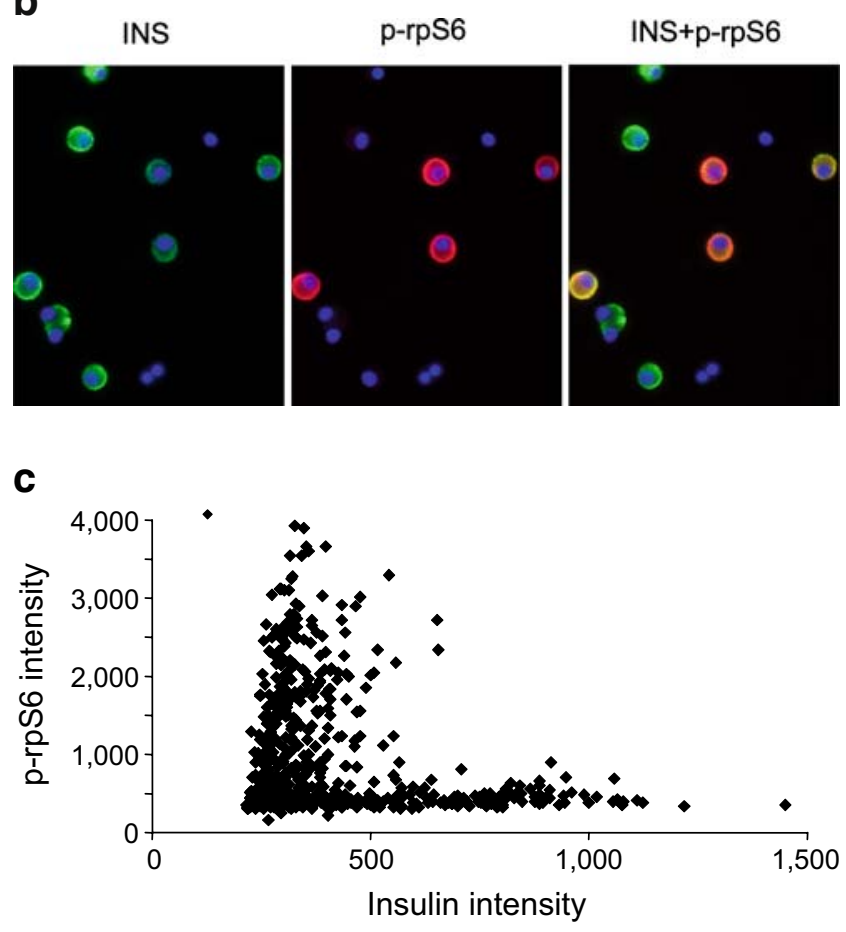

has been reported that the activation of ERKs, which are the downstream targets of MEK, activates MAP kinase signalintegrating kinases (MNKs) and consequently induce phosphorylation of eIF4E [44] and translation [45]. Here, we did not find evidence for this pathway, since the glibenclamide-induced ERK phosphorylation was unaffected by the MEK inhibitors U0126 and PD98059.
Fig. 7 Effects of glibenclamide on abundance of phospho-rpS6 in individual beta cells. a Purified single rat beta cells were cultured for $24 \mathrm{~h}$ at $6 \mathrm{mmol} / \mathrm{l}$ glucose without (Control) or with $4 \mu \mathrm{mol} /$ 1 glibenclamide (Glib), in absence (NO) or presence of $10 \mu \mathrm{mol} /$ 1 verapamil (Verap) or of $25 \mathrm{nmol} / 1$ rapamycin (Rapa). By the end of culture, cells were stained with anti-phospho-rpS6 antibody (p-rpS6, red) and Hoechst33342 (blue). Images are representative of five independent experiments. b Cells treated for $24 \mathrm{~h}$ with glibenclamide were stained with p-rpS6 (red) and insulin antibodies (INS, green) and Hoeschst (blue). Individual cells were plotted for the intensity of their p-rpS6- and insulin-staining as analysed by the BD pathway bioimager. The scatter plot (c) shows that the p-rpS6-positive cells correspond to beta cells with lower insulin content. The panel is representative of three independent experiments

Based on the present observations, we propose a model for glibenclamide-induced translation activation (Fig. 8). The sustained elevation in intracellular calcium is expected to activate mTOR signalling via PKA/PKB-dependent and independent pathways, thus leading to phosphorylation of 4E-BP1, which promotes cap-dependent translation initiation $[13,16]$, and of $\mathrm{rpS6}$, which increases ribosomal biogenesis [14]. In addition, the calcium induced PKA signalling will lead to eEF2-dephosphorylation, thus facilitating peptide chain elongation $[15,38]$. The rise in calcium will also increase translation initiation by dephosphorylating eIF2 $\alpha[11,16]$ through mTOR- and PKAindependent pathways. It is still unclear how translation could be activated through MEK signalling.

So far, translational control of insulin synthesis has been primarily demonstrated and investigated for agents that exert an acute stimulation on the rate of hormone pro-

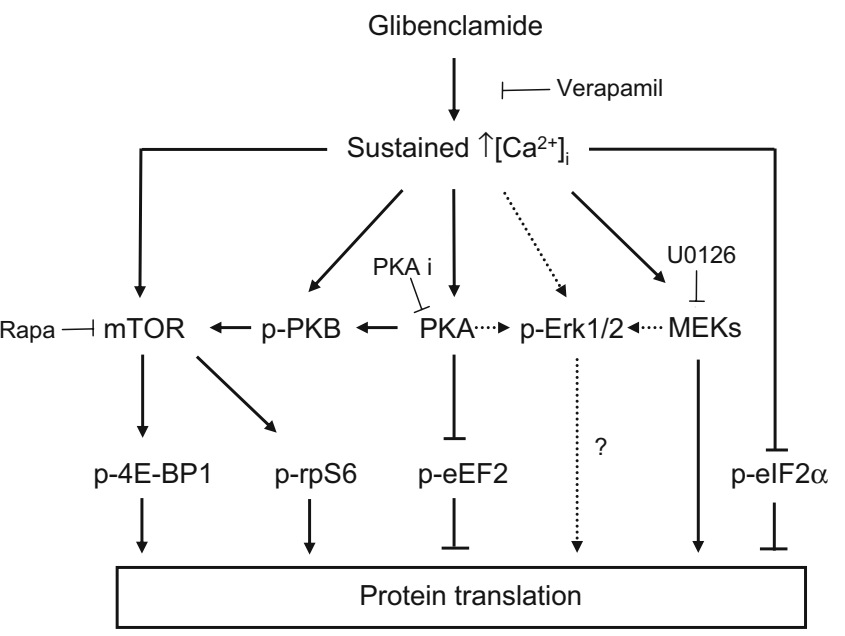

Fig. 8 Signalling pathways in glibenclamide-induced activation of translation. Prolonged exposure to insulin-releasing concentrations of glibenclamide maintains an elevated intracellular calcium concentration which leads to an activation of: (1) mTOR via PKA/PKB-dependent and -independent pathways, with subsequent phosphorylation of the translational factors 4E-BP1 and rpS6; (2) PKA signalling leading to dephosphorylation of eEF2; (3) dephosphorylation of eIF2 $\alpha$; and (4) MEK signalling activating an as yet unidentified translational regulator. $\left[\mathrm{Ca}^{2+}\right]_{\mathrm{i}}$, intracellular calcium 
duction such as glucose and exendin 4 [12, 46-48]. This effect accompanies their acute glucose-dependent stimulation of insulin release and can therefore help sustain cellular insulin reserves. The present study demonstrates that translation can also be activated following prolonged exposure to glibenclamide, an insulin secretagogue with rapid effects on insulin release but not synthesis [3, 48, 49]. This activation was induced during culture at $6 \mathrm{mmol} / \mathrm{l}$ glucose and results in an elevated basal rate of insulin synthesis that is independent of glucose, as is the glibenclamideinduced insulin release [50]. It might therefore be relevant to in vivo conditions, where this agent is used to generate a sustained elevation of circulating insulin, possibly increasing the risk of hypoglycaemic episodes in patients treated with this drug.

In conclusion, prolonged exposure of pancreatic beta cells to the insulin secretagogue glibenclamide activates translation initiation and elongation factors and thus the basal rates of insulin synthesis. This chronic effect of the sulfonylurea drug is calcium-dependent and mediated through the mTOR, PKA and MEK pathways. In the rat beta cell populations studied here this effect was predominantly achieved in the subpopulation of beta cells that have been degranulated by the agent.

Acknowledgements This study was supported by the Research Foundation Flanders (Fonds Voor Wetenschappelijk Onderzoek-Vlaan-deren Grant FWO-G.0183.05, G.0400.07), by the Inter-University Poles of Attraction Program (IUAP P5/17) from the Belgian Science Policy, by the Onderzoeksraad Vrije Universiteit Brussel (OZR. 1153), by the European Commission Sixth Framework Programme (FP6. 512145) and by the E-Institutes of Shanghai Universities.

We thank R. De Proft, G. Stangé and the staff of the Diabetes Research Center for technical assistance.

Duality of interest The authors declare that there is no duality of interest associated with this manuscript.

\section{References}

1. Pipeleers D, Kiekens R, Ling Z, Wilikens A, Schuit F (1994) Physiologic relevance of heterogeneity in the pancreatic beta-cell population. Diabetologia 37(Suppl 2):S57-S64

2. Ling Z, Kiekens R, Mahler T et al (1996) Effects of chronically elevated glucose levels on the functional properties of rat pancreatic beta-cells. Diabetes 45:1774-1782

3. Ling Z, Wang Q, Stange G, In't Veld P, Pipeleers D (2006) Glibenclamide treatment recruits beta-cell subpopulation into elevated and sustained basal insulin synthetic activity. Diabetes 55:78-85

4. Yamato E, Ikegami H, Tahara Y et al (1994) Glyburide enhances insulin gene expression and glucose-induced insulin release in isolated rat islets. Biochem Biophys Res Commun 199:327-333

5. Yamato E, Ikegami H, Tahara Y et al (1993) Cellular mechanism of glyburide-induced insulin gene expression in isolated rat islets. Biochem Biophys Res Commun 197:957-964
6. Guiot Y, Henquin JC, Rahier J (1994) Effects of glibenclamide on pancreatic beta-cell proliferation in vivo. Eur J Pharmacol 261:157-161

7. Kwon G, Marshall CA, Liu H, Pappan KL, Remedi MS, McDaniel ML (2006) Glucose-stimulated DNA synthesis through mammalian target of rapamycin (mTOR) is regulated by KATP channels: effects on cell cycle progression in rodent islets. J Biol Chem 281:3261-3267

8. Kwon G, Marshall CA, Pappan KL, Remedi MS, McDaniel ML (2004) Signaling elements involved in the metabolic regulation of mTOR by nutrients, incretins, and growth factors in islets. Diabetes 53(Suppl 3):S225-S232

9. Gingras AC, Raught B, Sonenberg N (2001) Regulation of translation initiation by FRAP/mTOR. Genes Dev 15:807-826

10. Proud CG (2007) Signaling to translation: how signal transduction pathways control the protein synthetic machinery. Biochem J 403:217-234

11. Proud CG (2005) eIF2 and the control of cell physiology. Semin Cell Dev Biol 16:3-12

12. Xu G, Marshall CA, Lin TA et al (1998) Insulin mediates glucosestimulated phosphorylation of PHAS-I by pancreatic beta cells. An insulin-receptor mechanism for autoregulation of protein synthesis by translation. J Biol Chem 273:4485-4491

13. Richter JD, Sonenberg N (2005) Regulation of cap-dependent translation by eIF4E inhibitory proteins. Nature 433:477-480

14. Meyuhas O (2000) Synthesis of the translational apparatus is regulated at the translational level. Eur J Biochem 267:6321-6330

15. Browne GJ, Proud CG (2002) Regulation of peptide-chain elongation in mammalian cells. Eur J Biochem 269:5360-5368

16. Hershey JWB, Merrick WC (2000) The pathway and mechanism of initiation of protein synthesis. In: Sonenberg N, Mathews MB, Hershey JWB (eds) Translational control of gene expression, 2nd edn. Cold Spring Harbor Laboratory Press, New York, pp 33-88

17. McDaniel ML, Marshall CA, Pappan KL, Kwon G (2002) Metabolic and autocrine regulation of the mammalian target of rapamycin by pancreatic beta-cells. Diabetes 51:2877-2885

18. Kleijn M, Scheper GC, Voorma HO, Thomas AA (1998) Regulation of translation initiation factors by signal transduction. Eur J Biochem 253:531-544

19. Pipeleers DG, in’t Veld PA, Van de Winkel M, Maes E, Schuit FC, Gepts W (1985) A new in vitro model for the study of pancreatic A and B cells. Endocrinology 117:806-816

20. Maedler K, Carr RD, Bosco D, Zuellig RA, Berney T, Donath MY (2005) Sulfonylurea induced beta-cell apoptosis in cultured human islets. J Clin Endocrinol Metab 90:501-506

21. Schuit FC, Kiekens R, Pipeleers DG (1991) Measuring the balance between insulin synthesis and insulin release. Biochem Biophys Res Commun 178:1182-1187

22. Martens GA, Wang Q, Kerckhofs K, Stange G, Ling Z, Pipeleers D (2006) Metabolic activation of glucose low-responsive betacells by glyceraldehyde correlates with their biosynthetic activation in lower glucose concentration range but not at high glucose. Endocrinology 147:5196-5204

23. Lehtihet M, Welsh N, Berggren PO, Cook GA, Sjoholm A (2003) Glibenclamide inhibits islet carnitine palmitoyltransferase 1 activity, leading to PKC-dependent insulin exocytosis. Am J Physiol Endocrinol Metab 285:E438-E446

24. Ball AJ, McCluskey JT, Flatt PR, McClenaghan NH (2004) Chronic exposure to tolbutamide and glibenclamide impairs insulin secretion but not transcription of K(ATP) channel components. Pharmacol Res 50:41-46

25. Shi H, Moustaid-Moussa N, Wilkison WO, Zemel MB (1999) Role of the sulfonylurea receptor in regulating human adipocyte metabolism. FASEB J 13:1833-1838

26. Jaber LA, Antal EJ, Slaughter RL, Welshman IR (1994) Comparison of pharmacokinetics and pharmacodynamics of short- and long-term glyburide therapy in NIDDM. Diabetes Care 17:1300-1306 
27. Rydberg T, Jonsson A, Karlsson MO, Melander A (1997) Concentration-effect relations of glibenclamide and its active metabolites in man: modelling of pharmacokinetics and pharmacodynamics. Br J Clin Pharmacol 43:373-381

28. Proks P, Reimann F, Green N, Gribble F, Ashcroft F (2002) Sulfonylurea stimulation of insulin secretion. Diabetes 51(Suppl 3):S368-S376

29. Sturgess NC, Ashford ML, Cook DL, Hales CN (1985) The sulphonylurea receptor may be an ATP-sensitive potassium channel. Lancet 2:474-475

30. Anello M, Gilon P, Henquin JC (1999) Alterations of insulin secretion from mouse islets treated with sulphonylureas: perturbations of $\mathrm{Ca}^{2+}$ regulation prevail over changes in insulin content. Br J Pharmacol 127:1883-1891

31. Ballou LM, Jiang YP, Du G, Frohman MA, Lin RZ (2003) Ca(2+)and phospholipase D-dependent and -independent pathways activate mTOR signaling. FEBS Lett 550:51-56

32. Hui AS, Bauer AL, Striet JB, Schnell PO, Czyzyk-Krzeska MF (2006) Calcium signaling stimulates translation of HIF-alpha during hypoxia. FASEB J 20:466-475

33. Yano S, Tokumitsu H, Soderling TR (1998) Calcium promotes cell survival through CaM-K kinase activation of the proteinkinase-B pathway. Nature 396:584-587

34. Avruch J, Lin Y, Long X, Murthy S, Ortiz-Vega S (2005) Recent advances in the regulation of the TOR pathway by insulin and nutrients. Curr Opin Clin Nutr Metab Care 8:67-72

35. Morgensztern D, McLeod HL (2005) PI3K/Akt/mTOR pathway as a target for cancer therapy. Anticancer Drugs 16:797-803

36. Lang CH, Frost RA (2007) Sepsis-induced suppression of skeletal muscle translation initiation mediated by tumor necrosis factor alpha. Metabolism 56:49-57

37. Gomez E, Powell ML, Greenman IC, Herbert TP (2004) Glucosestimulated protein synthesis in pancreatic beta-cells parallels an increase in the availability of the translational ternary complex (eIF2-GTP.Met-tRNAi) and the dephosphorylation of eIF2 alpha. J Biol Chem 279:53937-53946

38. Redpath NT, Price NT, Severinov KV, Proud CG (1993) Regulation of elongation factor-2 by multisite phosphorylation. Eur J Biochem 213:689-699
39. Diggle TA, Redpath NT, Heesom KJ, Denton RM (1998) Regulation of protein-synthesis elongation-factor-2 kinase by cAMP in adipocytes. Biochem J 336(Pt 3):525-529

40. Hovland R, Eikhom TS, Proud CG et al (1999) cAMP inhibits translation by inducing $\mathrm{Ca}^{2+} /$ calmodulin-independent elongation factor 2 kinase activity in IPC-81 cells. FEBS Lett 444:97-101

41. Straub SG, Sharp GW (2002) Glucose-stimulated signaling pathways in biphasic insulin secretion. Diabetes Metab Res Rev $18: 451-463$

42. Nesher R, Anteby E, Yedovizky M, Warwar N, Kaiser N, Cerasi E (2002) Beta-cell protein kinases and the dynamics of the insulin response to glucose. Diabetes 51(Suppl 1):S68-S73

43. Henquin JC (2000) Triggering and amplifying pathways of regulation of insulin secretion by glucose. Diabetes 49:1751-1760

44. Wang X, Flynn A, Waskiewicz AJ et al (1998) The phosphorylation of eukaryotic initiation factor eIF4E in response to phorbol esters, cell stresses, and cytokines is mediated by distinct MAP kinase pathways. J Biol Chem 273:9373-9377

45. Banko JL, Hou L, Klann E (2004) NMDA receptor activation results in PKA- and ERK-dependent Mnk1 activation and increased eIF4E phosphorylation in hippocampal area CA1. J Neurochem 91:462-470

46. Itoh N, Okamoto H (1980) Translational control of proinsulin synthesis by glucose. Nature 283:100-102

47. Yan L, Nairn AC, Palfrey HC, Brady MJ (2003) Glucose regulates EF-2 phosphorylation and protein translation by a protein phosphatase-2A-dependent mechanism in INS-1-derived 832/13 cells. J Biol Chem 278:18177-18183

48. Alarcon C, Wicksteed B, Rhodes CJ (2006) Exendin 4 controls insulin production in rat islet beta cells predominantly by potentiation of glucose-stimulated proinsulin biosynthesis at the translational level. Diabetologia 49:2920-2929

49. Schatz H, Maier V, Hinz M, Nierle C, Pfeiffer EF (1972) The effect of tolbutamide and glibenclamide on the incorporation of $(3 \mathrm{H})$ leucine and on the conversion of proinsulin to insulin in isolated pancreatic islets. FEBS Lett 26:237-240

50. Gorus FK, Schuit FC, In't Veld PA, Gepts W, Pipeleers DG (1988) Interaction of sulfonylureas with pancreatic beta-cells. A study with glyburide. Diabetes 37:1090-1095 